\title{
Nanofiltration as a cost-saving desalination process
}

\author{
Mohamed Kanber Wafi ${ }^{1}$ (D) - Nazir Hussain ${ }^{1}$. Osman El-Sharief Abdalla ${ }^{1} \cdot$ Mohammed Darwish Al-Far $^{1}$. \\ Najeya Ali Al-Hajaj ${ }^{1}$ Khero Farhan Alzonnikah ${ }^{1}$
}

(c) Springer Nature Switzerland AG 2019

\begin{abstract}
The water is a basic need for life including human beings, animals, plants, and microbial life. Although almost $75 \%$ of globe is covered by water in the form of oceans, only a small percentage of water is usable by living beings due to various salt content, pathogens, and contaminants. Good-quality water is highly scarce in dry regions of the world like Gulf Cooperation Council, South Asian and African countries. It is believed that the limited water supplies of water may worsen due to the inception of climatic changes ahead. The only alternative source is desalination of seawater/saline water. The traditional desalination technology is improving due to introduction of nanotechnologies like nanofiltration. The present studies were conducted at the research farm of Ministry of Municipalities and Environment (MME), Doha Qatar for 3 years (2016-2018). RO and nanofiltration plants were procured and installed at the research farm of MME. Electricity consumption was recorded, and quality of various types of water: feed water, product water, and brine water, was regularly monitored. The results of the study indicated that nanofiltration desalination process proved as effective as the RO but consumed $29 \%$ lesser energy. Therefore, the cost of water production was lessened by $29 \%$, thus making the desalination technology as cost-saving and feasible.
\end{abstract}

Keywords Desalination · Saline water - Good-quality water $\cdot$ Reverse osmosis (RO) $\cdot$ Feasibility of nanofiltration · Costsaving desalination technology

\section{Introduction}

Water is becoming highly important and precious due to climatic change scenario and escalating requirements of ever-increasing populations of the globe. Shahzad et al. [1] have pointed out that global water requirements by the year 2050 are estimated of upscaling to more than 60 billion $\mathrm{m}^{3}$ per year. The current century (21st) is going to prove of water, especially in the water deficit areas like Gulf Cooperation Council (GCC), South Asia, and many other countries. There is a severe deficiency of water for drinking, domestic use, and agricultural purposes in these countries, while Qatar is the most severe one due to almost no supplies of good-quality terrestrial water. The total water consumption in GCC countries has been reported as 26,150 MCM, which is $95 \%$ (Bahrain 167\%,
Kuwait 118\%, Oman 140\%, Qatar 150\%, Saudi Arabia 84\%, and UAE 131\%) increase during the decade 2000-2010 [2]. The project water demand of GCC will increase by 40 in $2030 \%$ and further $40 \%$ by 2040 , mainly due to increase in population [3]. Because of scanty supplies of potable water in these areas and global development of desalination technologies in the last 2-3 decades, obviously, seawater is the only future hope of these countries for meeting urgent water requirements [4]. Rubina and Mohammad [5] reported that the desalination technology proved highly useful to convert seawater to freshwater. Therefore, about $70 \%$ of desalinated water of the world is used in GCC countries only [6]. The ensured consistent supplies have increased usage of desalinated seawater and made it feasible as water resource for these countries, despite very high costs. A study by Water Reuse

$\triangle$ Mohamed Kanber Wafi, mjkwafi@hotmail.com | ${ }^{1}$ Agricultural Research Department, Ministry of Municipality and Environment, Doha, Qatar.

SN Applied Sciences (2019) 1:751 | https://doi.org/10.1007/s42452-019-0775-y 
Association [7] in 2012 indicated that cost of RO water (from seawater) varied from $\$ 0.79$ to $\$ 2.38$ per $\mathrm{m} 3$, while other authors [8] found it as $\$ 0.5-1.0$. The cost variations were due to many cost factors like qualities of feed water and product water, capacity of plant, location, price of electricity, etc.

Saline water/seawater desalination process extracts good-quality low saltwater from the saline/seawater and separates it into two types of water: a water of lesser dissolved salts and a high-salt concentrated brine water. There are so many technologies of desalination process like multistage flash distillation (MSF), multiple-effect distillation (MED), vapor compression distillation (VCD), reverse osmosis (RO), freezing, potabilization, solar evaporation, and multistage flash distillation (MFD). The most widely used technologies at present are reverse osmosis (RO) and multistage flash (MSF) distillation [9]. These processes require a lot of energy that increase the cost of unit volume of water making it unusable for many purposes like irrigation of crops grown on extensive areas. The energy requirements in the form of electricity may grow to $75.2 \mathrm{TWh}$ per year with $\mathrm{CO}_{2}$ emissions of $218 \mathrm{Mt}$ per year by 2040 [1]. They suggested that innovative hybrid desalination methods using high-flux membranes are required to reduce the cost of $\mathrm{RO}$ water. Then, there are also problem of fouling of membranes and disposal of brine water. Innovative technologies are emerging through consistent research and subsequent development for removing such deficiencies and improving the current tough situation [10]. In the improvement efforts of RO system, Moreno and Pinilla [11] developed and tested a wind power-driven $\mathrm{RO}$ desalination plant which could produce approximately $0.4 \mathrm{~m}^{3} / \mathrm{d}$ desalinated water and claimed to meet requirements of a community in an isolated location.

The use of nanotechnology for water desalination is one of the innovative techniques. Nanofiltration, a recently developed water purification process, is claimed just as effective as current methods but more energy efficient and potentially much less expensive [12]. Talaeipour et al. [13] in their studies in Iran calculated the salt rejection of $50 \% ; 70 \%$, and $74 \%$, respectively, using nanofiltration, reverse osmosis, and hybrid processes while $\mathrm{Na}$ removal proved better than $\mathrm{Cl}$ in both membranes and the hybrid system. However, fouling of membrane was reported after 4 months ( $2600 \mathrm{~h}$ ), but after cleaning, the flux was recovered by $95 \%$ of pre-fouled condition [14]. The research on nanoscale science and engineering has innovated techniques of desalination like nanosorbents, nanocatalysts, bioactive nanoparticles, nanostructured catalytic membranes, and nanoparticle enhanced filtration to resolve water quality problems. Additionally, nanotechnology-derived products can reduce the concentrations of toxic compounds and salts to match water quality standards for health [11, 15-17]. Mondal and Wickramasinghe [18] suggested that nanofiltration could be a viable technique even for treatment of oil and gas industry-produced water. Nanofiltration membranes successfully remove very small particles (0.001 micron), dissolved salts and minerals, sugars, metal ions, bacterial and viral pathogens, biological matter, latex and oil emulsions, carbon, proteins, and enzymes [19].

The testing of nanofiltration technology has been mostly in western countries. Therefore, verification of the claim of technology was highly important under Qatar conditions prior to recommending for adaptation in the country for various objectives like drinking, industry, and irrigation of crops grown in greenhouses. Therefore, a project was planned and submitted to Qatar Foundation under its NPRP (National Priorities Research Program), which was approved and sponsored by this organization and subsequently implemented by Ministry of Municipalities and Environment Qatar during 2015-2018. The major objectives of this project are many, but the component of the present paper is targeting comparison of cost and quality of water from RO and nanofiltration.

\section{Methodology}

\subsection{Procurement of desalination plants and their operational characteristics}

The desalination plants ( $\mathrm{RO}$ and nanofiltration, NF) were procured from the market with the financial support from Qatar Foundation and installed on December 01, 2016, at experimental site of MME (Ministry of Municipalities and Environment), Al Utoriya Agricultural Research Farm (Fig. 1). The source of feed water was saline groundwater of this location (Sect. 2.2).

The basic operational characteristics, flow diagram of $\mathrm{RO}$ unit as well as nanofiltration unit are presented in the text box and Figs. 2 and 3, respectively. 


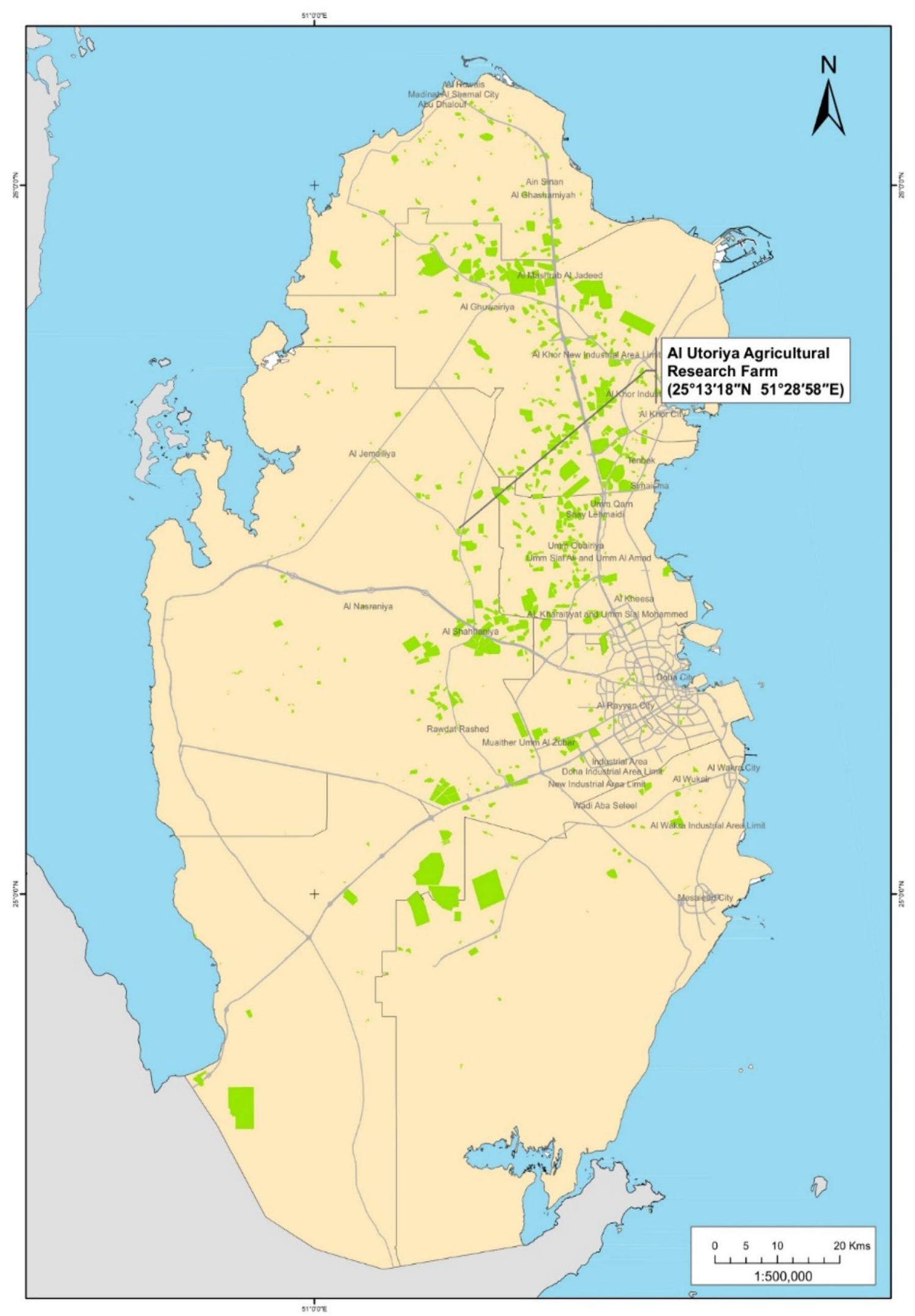

Fig. 1 Location map of MME- Al Utoriya agricultural research farm, Qatar 
Fig. 2 Process flow diagram of RO plant

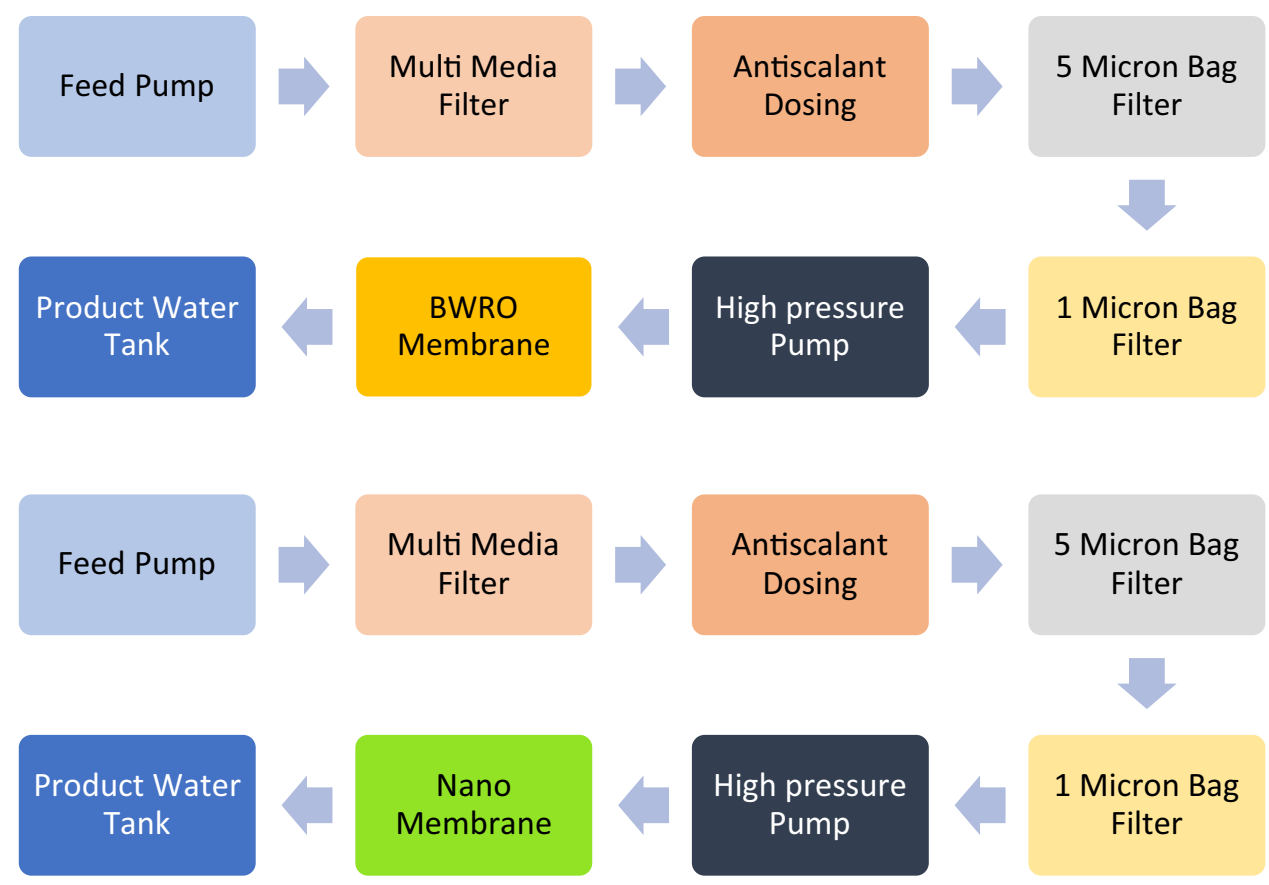

Fig. 3 Process flow diagram of nanoplant

\begin{tabular}{|c|c|c|}
\hline $\begin{array}{l}\text { Operational param- } \\
\text { eters and specifica- } \\
\text { tions }\end{array}$ & RO plant & Nanoplant \\
\hline Feed flow rate & $1.2 \mathrm{~m}^{3} / \mathrm{h}$ & $1.2 \mathrm{~m}^{3} / \mathrm{h}$ \\
\hline Recovery & Average $17 \%$ & Average $17 \%$ \\
\hline Permeate flow rate & $\begin{array}{l}0.208 \mathrm{~m}^{3} / \mathrm{h}\left(5 \mathrm{~m}^{3} /\right. \\
\text { day })\end{array}$ & $0.208 \mathrm{~m}^{3} / \mathrm{h}\left(5 \mathrm{~m}^{3} /\right.$ day $)$ \\
\hline Operating hours & 24 h/day & 24 h/day \\
\hline $\begin{array}{l}\text { Expected permeate } \\
\text { TDS }\end{array}$ & $\begin{array}{l}\text { Less than } 24 \mathrm{ppm} \text { at } \\
25^{\circ} \mathrm{C}\end{array}$ & $\begin{array}{l}\text { Less than } 600 \mathrm{ppm} \\
\text { at } 25^{\circ} \mathrm{C} \text {, but can } \\
\text { be adjusted at any } \\
\text { value lesser than it }\end{array}$ \\
\hline Feed salinity & $1000-2000$ ppm & $1000-2000$ ppm \\
\hline Design salinity & 3000 ppm (max) & 3000 ppm (max) \\
\hline \multicolumn{3}{|l|}{ Specification } \\
\hline Brand & Hydranautics & Hydranautics \\
\hline Country of origin & Japan/USA & USA \\
\hline Element size & $\begin{array}{l}4 \text { in. Dia } \times 40 \text { in. } \\
\text { length }\end{array}$ & $\begin{array}{l}4 \text { inches Dia } \times 40 \text { in. } \\
\text { length }\end{array}$ \\
\hline $\begin{array}{l}\text { Material of con- } \\
\text { struction }\end{array}$ & Thin-film composite & Thin-film composite \\
\hline \multicolumn{3}{|l|}{ Instrumentation } \\
\hline $\begin{array}{l}\text { Pressure gauge/ } \\
\text { location }\end{array}$ & $\begin{array}{l}\text { Across multimedia } \\
\text { filter and across } \\
\text { RO unit }\end{array}$ & $\begin{array}{l}\text { Across multimedia } \\
\text { filter and across } \\
\text { nano-UNIT }\end{array}$ \\
\hline $\begin{array}{l}\text { Temperature } \\
\text { gauge/location }\end{array}$ & At inlet & At inlet \\
\hline $\begin{array}{l}\text { Flow meter/loca- } \\
\text { tion }\end{array}$ & $\begin{array}{l}\text { RO product and } \\
\text { reject }\end{array}$ & $\begin{array}{l}\text { Nanoproduct and } \\
\text { reject }\end{array}$ \\
\hline
\end{tabular}

\begin{tabular}{lll}
\hline $\begin{array}{l}\text { Operational param- } \\
\text { eters and specifica- } \\
\text { tions }\end{array}$ & RO plant & Nanoplant \\
\hline $\begin{array}{c}\text { Conductivity } \\
\text { meter/location }\end{array}$ & At RO product & At nanoproduct \\
$\begin{array}{c}\text { Low-pressure cut- } \\
\text { off/location } \\
\text { application }\end{array}$ & $\begin{array}{c}\text { Low-pressure cut-off/ } \\
\text { location } \\
\text { High-pressure } \\
\text { pump suction line }\end{array}$ & $\begin{array}{c}\text { High-pressure pump } \\
\text { suction line }\end{array}$ \\
\hline
\end{tabular}

\subsection{Recording of volume of desalinated water and subsequent analysis}

Volume of permeate water and electricity consumption were recorded every day. Electricity meter reading for RO and nanowater plants was recorded separately for making comparison of energy consumption. The $\mathrm{pH}$ and electrical conductivity (EC) were recorded regularly throughout the experimental period using digitized system.

Samples of product water from both units as well as brine water were collected at the start and once a month and analyzed during the entire growing season of vegetables (from September to April in 2016-2017 and 2017-2018) in the MME Central Agricultural Lab (Tables 1, $2,3)$. Vegetable growing with RO permeate and NF permeate was the second component of the whole project. Collected samples of feed water, RO permeate water, 
Table 1 Characteristics of different types of water (average of 5 times sampling, once each month during 2016-2017)

\begin{tabular}{|c|c|c|c|c|c|c|c|c|c|c|c|c|}
\hline \multirow[t]{2}{*}{ Types of water } & \multirow[t]{2}{*}{$\mathrm{pH}$} & \multirow[t]{2}{*}{$\mathrm{EC}(\mathrm{dS} / \mathrm{m})$} & \multirow[t]{2}{*}{ TDS (Ppm) } & \multirow[t]{2}{*}{ SAR } & \multicolumn{4}{|c|}{ Anions (me/l) } & \multicolumn{4}{|c|}{ Cations (me/l) } \\
\hline & & & & & $\mathrm{CO}_{3}$ & $\mathrm{HCO}_{3}$ & $\mathrm{Cl}$ & $\mathrm{SO}_{4}$ & $\mathrm{Ca}$ & $\mathrm{Mg}$ & $\mathrm{Na}$ & K \\
\hline Feed water & 8.04 & 4.67 & 2802 & 12.76 & 0 & 6.12 & 27.04 & 14.10 & 10.91 & 7.42 & 38.61 & 1.15 \\
\hline RO water & 6.07 & 0.04 & 23.3 & 0.79 & 0 & 0.42 & 0.37 & 0.01 & 0.14 & 0.03 & 0.23 & 0.03 \\
\hline Nanowater & 7.74 & 0.94 & 562 & 5.83 & 0 & 2.26 & 6.01 & 0.89 & 1.32 & 0.96 & 6.23 & 0.60 \\
\hline Brine water & 8.18 & 5.03 & 3016 & 5.59 & 0 & 8.04 & 25.00 & 19.45 & 16.18 & 9.10 & 19.88 & 2.13 \\
\hline
\end{tabular}

Table 2 Characteristics of different types of water (average of 6 times sampling, once each month during 2017-2018)

\begin{tabular}{|c|c|c|c|c|c|c|c|c|c|c|c|c|}
\hline \multirow[t]{2}{*}{ Type of water } & \multirow[t]{2}{*}{$\mathrm{pH}$} & \multirow[t]{2}{*}{$\mathrm{EC}(\mathrm{dS} / \mathrm{m})$} & \multirow[t]{2}{*}{ TDS (ppm) } & \multirow[t]{2}{*}{ SAR } & \multicolumn{4}{|c|}{ Anions (me/l) } & \multicolumn{4}{|c|}{ Cations (me/l) } \\
\hline & & & & & $\mathrm{CO}_{3}$ & $\mathrm{HCO}_{3}$ & $\mathrm{Cl}$ & $\mathrm{SO}_{4}$ & $\mathrm{Ca}$ & $\mathrm{Mg}$ & $\mathrm{Na}$ & $\mathrm{K}$ \\
\hline Feed water & 7.73 & 5.00 & 3002 & 12.95 & 0 & 4.43 & 33.74 & 10.14 & 8.48 & 5.92 & 34.70 & 0.89 \\
\hline RO water & 6.41 & 0.08 & 50.0 & 1.69 & 0 & 0.56 & 0.83 & 0.07 & 0.19 & 0.07 & 0.61 & 0.04 \\
\hline Nanowater ${ }^{\mathrm{a}}$ & 6.21 & 0.06 & 38.0 & 1.97 & 0 & 0.46 & 0.66 & 0.04 & 0.11 & 0.04 & 0.54 & 0.02 \\
\hline Brine water & 7.77 & 6.78 & 4071 & 15.85 & 0 & 5.06 & 48.90 & 8.92 & 9.50 & 6.86 & 45.33 & 1.19 \\
\hline
\end{tabular}

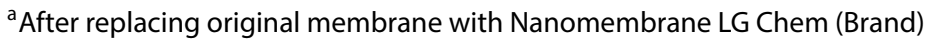

Table 3 Comparison of total energy consumption, water productivity, and cost of energy

\begin{tabular}{|c|c|c|c|c|c|c|}
\hline \multirow[t]{3}{*}{ Dates of plant operation } & \multicolumn{6}{|c|}{ Energy and water consumption parameters } \\
\hline & \multirow[t]{2}{*}{$\begin{array}{l}\text { Total energy con- } \\
\text { sumption (kwh) }\end{array}$} & \multirow[t]{2}{*}{$\begin{array}{l}\text { Total water desali- } \\
\text { nated }\left(\mathrm{m}^{3}\right)\end{array}$} & \multicolumn{2}{|c|}{$\begin{array}{l}\text { Unit cost of product water (QR/ } \\
\left.\mathrm{m}^{3}\right)\end{array}$} & \multicolumn{2}{|c|}{$\begin{array}{l}\text { Cost of total energy consump } \\
\text { tion (QR) }\end{array}$} \\
\hline & & & $\begin{array}{l}\text { At the subsi- } \\
\text { dized rate }^{\mathrm{a}}\end{array}$ & $\begin{array}{l}\text { At the commer- } \\
\text { cial rate }{ }^{b}\end{array}$ & $\begin{array}{l}\text { At the subsi- } \\
\text { dized rate }\end{array}$ & $\begin{array}{l}\text { At the com- } \\
\text { mercial rate }\end{array}$ \\
\hline \multicolumn{7}{|l|}{ RO unit } \\
\hline $19 / 12 / 2016-30 / 5 / 2017$ & 193.73 & 59.95 & 0.226 & 32.31 & 13.56 & 1937 \\
\hline $1 / 10 / 2017-25 / 4 / 2018$ & 370.53 & 80.44 & 0.322 & 46.06 & 25.94 & 3705 \\
\hline Mean for two seasons & 282.13 & 70.19 & 0.281 & 40.19 & 19.75 & 2821 \\
\hline \multicolumn{7}{|l|}{ Nanofiltration unit } \\
\hline $19 / 12 / 2016-30 / 5 / 2017$ & 139.94 & 60.12 & 0.163 & 23.27 & 9.80 & 1399 \\
\hline $1 / 10 / 2017-25 / 4 / 2018$ & 266.57 & 81.13 & 0.230 & 32.86 & 18.66 & 2666 \\
\hline Mean for two seasons & 203.26 & 70.62 & 0.202 & 28.77 & 14.23 & 2032 \\
\hline
\end{tabular}

${ }^{\mathrm{a}}$ The tariff of Qatar general electricity and water cooperation (KAHRAMAA)—For productive farm $=0.07 \mathrm{QR} / \mathrm{kwh}=0.02 \mathrm{USD} / \mathrm{kwh}$

${ }^{\mathrm{b}}$ Commercial rate $=10.0 \mathrm{QR} / \mathrm{kwh}$-One USD $=3.65$ Qatari rail $(\mathrm{QR})$

nanopermeate water, and brine water were analyzed. Water productivity ( $\mathrm{m}^{3} / \mathrm{kwh}$ of electricity) was calculated.

Feed water entering the desalination plants was also analyzed for its quality. In the first year, average electrical conductivity (EC) of feed water was $4.64 \mathrm{mS} / \mathrm{cm}$, TDS 2784 ppm, and pH 8.04. In the second year, average values of electrical conductivity (EC) $5.0 \mathrm{mS} / \mathrm{cm}$, TDS $3001.67 \mathrm{ppm}$, and $\mathrm{pH} 7.73$ were recorded.

\section{Results}

After the procurement and installation of RO and nanofiltration plants, their operation was tested. It was found that both of the plants and their digital systems were working very well. Some test readings were recorded to make sure of repeatability and consistency. Thus, water of different qualities became available on December 19, 2016, which could be used for various purposes like drinking, home 
consumption, and particularly for irrigation of vegetable crops being grown in greenhouses. Subsequently, first and second crops of tomato, cucumber, and capsicum were grown successfully. Yields data of crops were recorded after harvesting which will be reported in a separate research paper. The electricity consumption and comparison, as well as quality of permeate water from the RO and nanofiltration plants, are being presented and discussed subsequently.

\subsection{Water productivity}

Water productivity is volume $\left(\mathrm{m}^{3}\right)$ of permeate water desalinated by desalination plants ( $\mathrm{RO}$ and nanofiltration plants in the present case) using one kw (kilowatt) per hour (h) of electricity. Thus, it is cubic meter $\left(\mathrm{m}^{3}\right)$ of water per kwh of electricity. Figures 4 and 5 show the comparative production of water and consumption of electricity by RO and nano-units between 19/12/2016 and 30/5/2017, and $1 / 10 / 2017$ and $25 / 4 / 2018$, respectively. It is very clear from the recorded data (Figs. 4, 5) that nanofiltration plant consumes lesser of electricity compared with RO water. In
Fig. 4 Comparison of energy consumption (kwh) by RO and nanoplants between $19 / 12 / 2016$ and 30/5/2017
Fig. 5 Comparison of energy consumption (kwh) by RO and nanoplants between $1 / 10 / 2017$ and $25 / 4 / 2018$

\section{Comparative Energy Consumption by RO and Nano \\ Units}

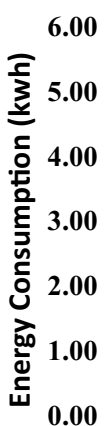

Leatoriya Farm -Qatar

19/12/2016 -30/5/2017

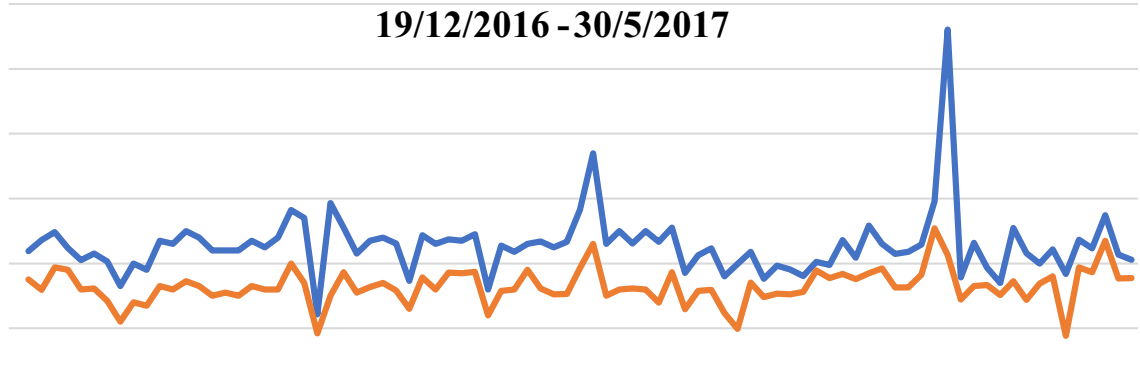

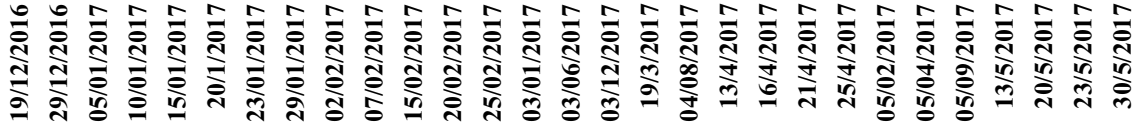

Date

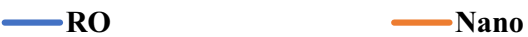

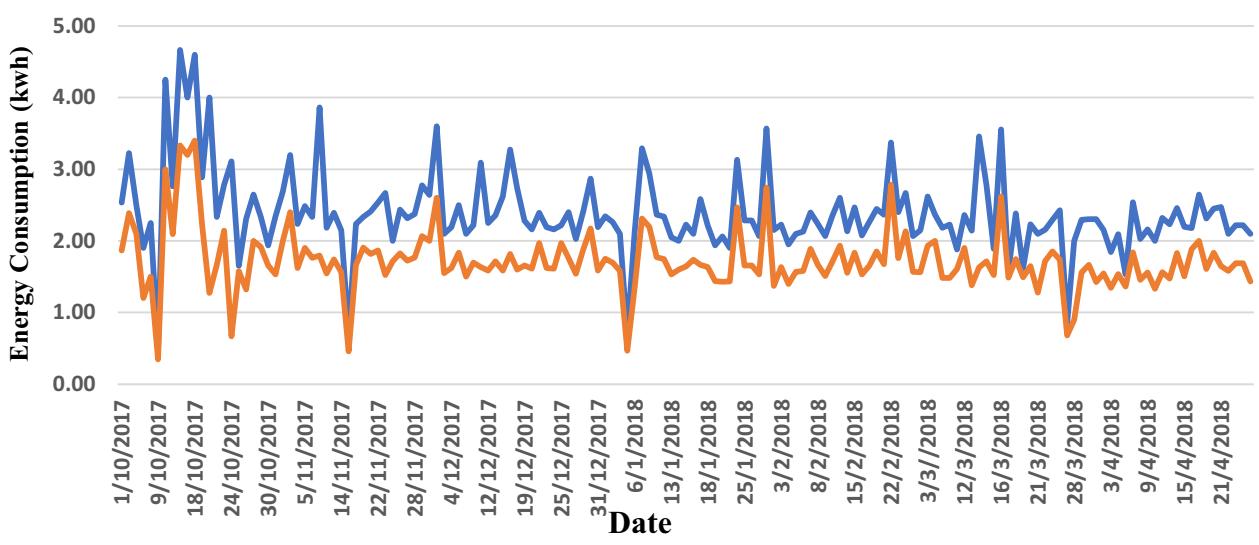

-RO Nano

SN Applied Sciences 
the first year, the average productivity of RO unit has been calculated as $0.095 \mathrm{~m}^{3} / \mathrm{kwh}$ with maximum as $0.193 \mathrm{~m}^{3} /$ $\mathrm{kwh}$ and minimum as $0.037 \mathrm{~m}^{3} / \mathrm{kwh}$, whereas the average for nanoplant is $0.134 \mathrm{~m}^{3} / \mathrm{kwh}$ with respective minimum and maximum values as $0.078 \mathrm{~m}^{3} / \mathrm{kwh}$ and $0.274 \mathrm{~m}^{3} /$ $\mathrm{kwh}$. Thus, the productivity of nanoplant was higher. The calculations indicated that consumption of electricity by nanofiltration plant was about $29.1 \%$ lesser than RO plant.

In the second year, the average productivity of RO unit has been calculated as $0.089 \mathrm{~m}^{3} / \mathrm{kwh}$ with maximum as $0.423 \mathrm{~m}^{3} / \mathrm{kwh}$ and minimum as $0.0 .043 \mathrm{~m}^{3} / \mathrm{kwh}$. However, the average, minimum, and maximum values for nanoplant are $0.125 \mathrm{~m}^{3} / \mathrm{kwh}, 0.062 \mathrm{~m}^{3} / \mathrm{kwh}$, and $0.609 \mathrm{~m}^{3} / \mathrm{kwh}$. Thus, the productivity of nanofiltration plant remained at higher rates in the second year as well. The consumption of electricity for second year by nanomembrane was about $28.9 \%$ lesser than RO plant.

The 2-year average electricity consumption by nanofiltration plant has been calculated as $29 \%(29.1+28.9$ divided by $2=29 \%$ ) lesser than RO. Thus, nanofiltration plant is $29 \%$ lesser consumer of electricity, meaning that water production is possible at $29 \%$ lesser cost in case of nanomembrane because electricity is highly costly item that determines price of desalinated water if all other factors are uniform and constant. The company claim was $30 \%$, which is very nearer to the found saving of $29 \%$. Results of this study agree to those of Silva et al. [12] who reported that nanofiltration is equally effective as RO but lesser in energy consumption. Some other studies also support these findings $[19,14,13]$.

\subsection{The quality of different types of water}

The qualities of various water types are presented in Tables 2 and 3 for the study period (December 2016 to April 2018). The feed water was saline which varied from EC 4.67-5.0 dS/m. The pH of this water varied from 7.73 to 8.04 indicating that water was alkaline. The dominating cation was $\mathrm{Na}^{+}$(varying from 34.70 to $38.61 \mathrm{me} / \mathrm{l}$ ), whereas major anions were $\mathrm{Cl}^{-}(27.04-33.74 \mathrm{me} / \mathrm{l})$ and $\mathrm{SO}_{4}$ (10.14-14.10 me/l) with minor quantities of $\mathrm{HCO}_{3}$ (4.44-6.12 me/l). This analysis indicates that although the quality of feed water was not consistent throughout the 2 years of study, the variations were not very wide.

The RO water was having acidic $\mathrm{pH}$ (6.07-6.41), very low TDS (23.2-50.0), and nominal values of SAR (0.79-1.69), indicating very lesser values of dissolved salts during both of the years (Tables 1, 2). Most of the monovalent as well as divalent ions were removed from the feed water. The $\mathrm{pH}$ of water from nanofiltration plant was alkaline (7.74) for the first year but found as acidic (6.21) in the second year. Similarly, TDS (mean 562 ppm) was higher in the first year as compared to the second year (mean $38 \mathrm{ppm}$ ), which was even lower than RO water (50 ppm). In the first year, the quality of nanofiltration membrane (Brand Hydranautics) was not very good and its choking occurred due to precipitation of $\mathrm{CaCO}_{3}$, which was overhauled with acid solution washing every week. However, in the second year, the membrane was changed with another brand (LG Chem Membrane element model ESNA1-LF2-LD 4040), which proved very effective, and quality of water was quite comparable with $\mathrm{RO}$ water. So, it is important that filtration membranes should be of very good quality of a dependable brand for effective performance.

The quality of RO and nanofiltration indicated that any one of these two waters can be used for various purposes like drinking, irrigation of plants, landscaping, and industry. Earlier studies in Iran [13] indicated a major part of salt rejection into brine water by using nanofiltration, reverse osmosis, and hybrid processes. In their research, $\mathrm{Na}$ removal was better than $\mathrm{Cl}$ in case of both membranes as well as the hybrid system. The brine water was alkaline $(\mathrm{pH}$ 7.17-8.18) and loaded with salts (TDS 3016-4070 ppm) in higher quantities, which were rejected from saline feed water by $\mathrm{RO}$ and nanomembranes in the present study as well (Tables 1, 2).

\section{Discussion}

Being the very good alternative of good-quality surface water, the use of RO water has almost been established in the countries and regions facing water scarcity, particularly in GCC countries. However, it is an accepted fact that RO water is very high priced $[8,7]$ and not affordable in many situations where cost is counted much. Since the inception, searches for its cheaper alternative were going on till the introduction of nanotechnologies in the water desalination field in the form of innovated nanofiltration technique [20]. Volkov et al. [21] mentioned that nanofiltration has extended its utilization in the fields of textile, paper, and food industries including water desalination in last decades. Dach [22] pointed out that a membrane process going to probably compete with $\mathrm{RO}$ for desalination of brackish water in the near future is nanofiltration.

In the present studies, almost equal volume of product water consumed more energy $(282.13 \mathrm{kWh})$ in the case of $\mathrm{RO}$ in comparison with nanofiltration (203.26 kWh) in both the years 2016-2017 and 2017-2018 (Table 3), which is $29 \%$ lesser in the case of nanofiltration. The average water productivity of RO plant $\left(0.249 \mathrm{~m}^{3} / \mathrm{kwh}\right)$ has been found lesser than nanofiltration $\left(0.347 \mathrm{~m}^{3} / \mathrm{kwh}\right)$. In studies of Maxime et al. [23], the membrane NF200 also indicated higher productivity $(1.8 \mathrm{~L} / \mathrm{h})$ and higher salt rejection (60\%). This membrane gave the best energy gain with $29 \%$ higher than RO. The total dissolved solids in the permeate were 324 ppm. However, they recommended further 
validation by experiments. The results of the present study agree as well to their findings. Having the similar results in his study, Dach [22] suggested that the rejections of salts increased with the feed pressure and decreased with the salt concentration and recovery rate in case of nanofiltration. Kuntyi et al. [24] explained that the characteristics of nanomaterials, like high reactivity and a high degree of functionalization, large specific surface area, are making these suitable for wastewater treatment and desalination of saline water. The results of Tay et al. [25] revealed that the NF-MBR achieved superior quality permeate because of biodegradation and high rejection capacity of the NF membrane, leading to lower fouling rates.

The calculations of the price of energy consumption revealed that unit cost of desalinated water from $\mathrm{RO}$ was $0.281 \mathrm{QR} / \mathrm{m}^{3}$ at the subsidized rate and $40.19 \mathrm{QR} / \mathrm{m}^{3}$ at the commercial rate of electricity (Table 3 ). The unit cost of nanofiltration water has been calculated as $0.202 \mathrm{QR} /$ $\mathrm{m}^{3}$ at the subsidized rate, whereas it is $28.77 \mathrm{QR} / \mathrm{m}^{3}$ at the commercial rate. Thus, the rates of unit cost are clearly lesser in the case of nanofiltration in comparison with RO. Similarly, cost of total electricity consumed is significantly lower in nanomembrane (subsidized rate $=14.23 \mathrm{QR}$ and at commercial rate $=2032 \mathrm{QR}$ ) as compared to $\mathrm{RO}$ (subsidized rate $=19.75 \mathrm{QR}$ and at commercial rate $=2821 \mathrm{QR}$ ). Hence, it can be concluded that nanofiltration produces comparable quality water at $29 \%$ lower rate and proved a cost-saving technology. Likewise, Silva et al. [12] claimed that nanofiltration is as effective as current methods but more energy efficient and potentially much less expensive.

Shahmansouri and Bellona [26] found nanofiltration technology as cost-effective for certain uses. They were of the view, however, that selection of NF over other treatment technologies depends on factors like pretreatment requirements and quality, feed water quality, treatment capacity, and treatment goals. The work of Elazhar et al. [27] showed that technically and economically, nanofiltration process is more convenient than the RO. The present study results suggested that quality of nanofiltration is almost comparable with $\mathrm{RO}$ water but at a cheaper rate of $29 \%$. This finding of the research study is highly favorable and useful for utilization of produced water for multi-purpose. The vegetable growers in greenhouses, especially in Qatar, can benefit and save their costs of production and supply vegetables to consumers at comparatively lower rates. The cheap-priced good-quality water can also be put to various other uses like growing of trees, ornamental plants, bushes, grasses, and flowers in landscaping. This water can also be used in the industrial sector to decrease the overall price of various processes and finally reduce the prices of products.

\section{Conclusions}

Investigations for comparing efficacy of RO and nanofiltration desalination processes were conducted at the Research Farm, Ministry of Municipalities and Environment (MME), Doha, Qatar, for the years 2015-2018. The salient results obtained are:

- The nano-unit is more energy efficient than RO unit in terms of producing desalinated water (product water) per unit of electricity because the 2-year average values of product water are $0.0130 \mathrm{~m}^{3} / \mathrm{kwh}$ and $0.092 \mathrm{~m}^{3} /$ kwh, respectively. Thus, the consumption of electricity by nanomembrane was about $29 \%$ lesser than RO plant. Therefore, accordingly, nanofiltration plant can produce desalinated water at $29 \%$ lesser price as compared to RO plant.

- The quality of product water by nanofiltration is equally comparable to $\mathrm{RO}$ in respect of TDS, $\mathrm{pH}, \mathrm{SAR}$, cations $(\mathrm{Ca}, \mathrm{Mg}, \mathrm{Na}$, and $\mathrm{K})$, and anions $\left(\mathrm{CO}_{3}, \mathrm{HCO}_{3}, \mathrm{Cl}, \mathrm{SO}_{4}\right)$. The salt content of permeate water by both plants is very low while $\mathrm{pH}$ is acidic.

- Thus, both of the water can be used for home consumption, landscaping, industry, and irrigation of vegetable crops in greenhouses of Qatar and other GCC countries. However, nanofiltration plant can save $29 \%$ of money, which incurred on desalination of water by this process.

- The nanofiltration plant has the potential for adjusting to receive any quality TDS water lesser than $600 \mathrm{ppm}$. Thus, if the water is planned to use for irrigation of crops, it can be calibrated to get water of TDS matching the variable tolerance of crops, avoiding more removal of divalent cations like $\mathrm{Ca}$ and $\mathrm{Mg}$, which are plant nutrients as well.

- Both of the membranes have the potential problem of fouling and choking due to precipitation of $\mathrm{CaCO}_{3}$ and must be overhauled using acid solutions after regular periods. Moreover, membranes should be of good quality, which must be ensured at the time of procurement.

Acknowledgements The financial sponsorship of these investigations by Qatar Foundation (Project No. NPRP 7-121-4-002) is thankfully acknowledged.

\section{Compliance with ethical standards}

Conflict of interest The authors declare that they have no competing interests. 


\section{References}

1. Shahzad MW, Burhan M, Ang L, Ng KC (2017) Engineering advance: energy-water-environment nexus underpinning future desalination sustainability. Desalination 413(1):52-64. https:// doi.org/10.1016/j.desal.2017.03.009

2. Al-Zubari W, Al-Turbak A, Zahid W, Al-Ruwis $\mathrm{K}, \mathrm{Al}$-Tkhais A, AlMuataz I, Abdelwahab A, Murad A, Al-Harbi M, Al-Sulaymani Z (2017) An overview of the GCC unified water strategy (20162035). Desalin Water Treat 81:1-18. https://doi.org/10.5004/ dwt.2017.20864

3. Almullah Y (2014) Gulf Cooperation Council (GCC) countries 2040 energy scenario for electricity generation and water desalination. Master of Science Thesis EGI 2014: Mar-Sep 2014, Modelling electricity and water desalination demand in the Gulf Cooperation Council (GCC) countries. KTH Industrial Engineering and Management, Sweden

4. IDA (2004) Desalting inventory 2004: desalination business stabilized on a high level. Int Desalin Water Reuse 14(2):14-17

5. Rubina B, Mohammad NAH (2013) Desalination: conversion of seawater to freshwater. In: Second international conference on mechanical, automotive and aerospace engineering (ICMAAE 2013) 2-4 July 2013, Kuala Lumpur. http://irep.iium. edu.my/34552/1/Paper_30156_-_Camera_ready.pdf

6. Al-Otaibi G (2015) By the numbers: facts about water crisis in the Arab World, The World Bank. http://blogs.worldbank.org/arabv oices/numbers-facts-about-water-crisis-arab-world. Retrieved 16 Apr 2019

7. Water Reuse Association (WRA) (2012) Seawater desalination costs, white paper 2012. https://watereuse.org/wp-content/ uploads/2015/10/WateReuse_Desal_Cost_White_Paper.pdf. Retrieved 16 Apr 2019

8. Ghaffour N, Missimer TM, Amy GL (2013) Technical review and evaluation of the economics of water desalination: current and future challenges for better water supply sustainability. Desalination 309:197-207. https://doi.org/10.1016/j.desal.2012.10.015

9. Khawaji AD, Kutubkhanah IK, Wie JM (2008) Advances in seawater desalination technologies. Desalination 221(2008):47-69

10. Chen J, Li G (2005) Marine reverse osmosis desalination plant-a case study. Desalination 174(3):299-303. https://doi. org/10.1016/j.desal.2004.10.004

11. Moreno F, Pinilla A (2004) Preliminary experimental study of a small reverse osmosis wind-powered desalination plant. Desalination 171(3):257-265. https://doi.org/10.1016/j.desal .2004.06.191

12. Silva V, Geraldes V, Brites Alves AM, Palacio L, Prádanos $P$, Hernández A (2011) Multi-ionic nanofiltration of highly concentrated salt mixtures in the seawater range. Desalination 277(1-3):29-39

13. Talaeipour M, Nouri J, Hassani AH, Mahvi AH (2017) An investigation of desalination by nanofiltration, reverse osmosis and integrated (hybrid NF/RO) membranes employed in brackish water treatment. J Environ Health Sci Eng 15:18. https://doi. org/10.1186/s40201-017-0279-x

14. Christopher JK, Robert B, Green J (2011) Utilizing nanotechnology to enhance RO membrane performance for seawater desalination. IDA World Congress-Perth Convention and Exhibition Centre (PCEC), Perth, Western Australia September 4-9, 2011, REF: IDAWC/PER11-323. file:///C:/Users/Aneeq/Desktop/ IDA_2011_Paper_Kurth.pdf

15. Noronha M, Mavrov V, Chmiel H (2002) Efficient design and optimization of two-stage NF processes by simplified process simulation. Desalination 145(1-3):207-215

16. Savage N, Diallo M (2005) Nanomaterials and water purification: opportunities and challenges. J Nanopart Res 7:331-342

17. Wang $X L$, Zhang CH, Zhao J (2000) Separation mechanism of nanofiltration membranes and its applications in food and pharmaceutical industries. Membr Sci Technol 20(1):29-30

18. Mondal S, Wickramasinghe SR (2008) Produced water treatment by nanofiltration and reverse osmosis membranes. J Membr Sci 322(1):162-170. https://doi.org/10.1016/j.memsci.2008.05.039

19. AXEON Water Technologies (2017) Basics of reverse osmosis and nanofiltration: desalination technologies and filtration processes. https://www.axeonwater.com/blog/reverse-osmos is-nanofiltration-desalination/

20. Eriksson $P$ (1988) Nanofiltration extends the range of membrane filtration. Environ Progress Sustain Energy 7(1):58-62. https:// doi.org/10.1002/ep.3300070116

21. Volkov VV, Mchedlishvili BV, Roldugin VI, Ivanchev SS, Yaroslavtsev AB (2008) Membranes and nanotechnologies. Nanotechnol Russ 3:656-687

22. Dach H (2008) Comparison of nanofiltration and reverse osmosis processes for a selective desalination of brackish water feeds. Doctoral Dissertation, Engineering Sciences (Physics), Université d'Angers

23. Maxime P, Derauw JS, Plantier S, Edouard L, Bailly L (2013) Seawater desalination: nanofiltration-A substitute for reverse osmosis? Desalin Water Treat 51(1):485-494. https://doi. org/10.1080/19443994.2012.714594

24. Kuntyi OI, Bukliv RL, Boyko YV, Hreben TV, Lysenko AV (2018) Nanomaterials and nanotechnology in water purification: review. Chem Technol Appl Subst 1(1):27-37

25. Tay FM, Liu C, Cornelissen ER, Wu B, Chong TH (2018) The feasibility of nanofiltration membrane bioreactor (NF-MBR) + reverse osmosis (RO) process for water reclamation: comparison with ultrafiltration membrane bioreactor (UF-MBR) + RO process. Water Res 129(1):180-189

26. Shahmansouri A, Bellona C (2015) Nanofiltration technology in water treatment and reuse: applications and costs. Water Sci Technol 71(3):309-319. https://doi.org/10.2166/wst.2015.015

27. Elazhar F, Touir J, Elazhar M, Belhamidi S, El-Harrak N, Zdeg A, Hafsi M, Amor Z, Taky M, Elmidaoui A (2015) Techno-economic comparison of reverse osmosis and nanofiltration in desalination of a Moroccan brackish groundwater. J Desalin Water Treat 55(9):2471-2477. https://doi.org/10.1080/19443994.2014.95973 9

Publisher's Note Springer Nature remains neutral with regard to jurisdictional claims in published maps and institutional affiliations. 